\title{
CAVE BIOFILMS: CHARACTERIZATION OF PHOTOTROPHIC CYANOBACTERIA AND ALGAE AND CHEMOTROPHIC FUNGI FROM THREE CAVES IN SERBIA
}

\author{
SlaĐana Popović ${ }^{1 *}$, Gordana Subakov Simić ${ }^{2}$, Miloš Stupar ${ }^{2}$, Nikola Unković ${ }^{2}$, Olivera Krunić ${ }^{3}$, \\ Nevena Savić ${ }^{3}$, and Milica Ljaljević Grbić ${ }^{2}$
}

\begin{abstract}
Cyanobacteria, algae (Chlorophyta and Bacillariophyta), and fungi were identified from biofilm samples from three caves in western Serbia: Ribnička, Hadži Prodanova, and Rćanska. Temperature, light intensity, and relative humidity varied from 16.9 ${ }^{\circ} \mathrm{C}$ to $24.9{ }^{\circ} \mathrm{C}, 61 \%$ to $87 \%$, and 215 Lux to 4400 Lux, respectively. In general, the highest number of documented taxa belonged to Cyanobacteria, with chroococcalean taxa prevailing and Gloeocapsa species as the most diverse. A large percentage of observed fungi were Ascomycetes or Zygomycetes, while the only representative of Basidiomycetes was Rhizoctonia s. lat. However, a redundancy analysis revealed that different taxonomic groups were dominant at different localities: cyanobacteria and fungi in Ribnička and Hadži Prodanova, and Chlorophyta and Bacillariophyta in Rćanska. The statistical analysis showed that relative humidity is an important physical parameter influencing the development of various microbial communities in different caves. Cyanobacteria were mostly found in places with lower relative humidity, while Chlorophyta and Bacillariophyta were found in places with higher humidity. The documented physical parameters did not have a significant impact on the distribution of fungi. Measured chlorophyll-a content was highest on horizontal surfaces, where the highest content of organic/inorganic matter were also recorded. The highest water content was observed in biofilm samples from which many cyanobacteria taxa were identified.
\end{abstract}

\section{INTRODUCTION}

The territory of Serbia is one of the curiosities of the world in terms of the complexity of the geological composition, both related to the number and diversity of lithologic and stratigraphic units, as well as in terms of tectonic structure. The geological heterogeneity of the territory is largely a consequence of magmatic activity accompanied by intense movements of the earth's crust during the Cretaceous and Tertiary Alpine tectonics. In a small area of $88,000 \mathrm{~km}^{2}$, the six major geotectonic regions (Inner Dinarides, ŠumadijskoKopaonička Zone, Serbian-Macedonian Mass, CarpathoBalkan Mountains, Moesian Platform, and the Pannonian Basin) (Dimitrijević, 1974), can be distinguished, along with dozens of lower-order geotectonic areas or units. Carpatho Balkanids and Inner Dinarides of western Serbia are regions where the terrain is built of carbonate sediments with very distinctive karst forms, both on the surface and underground (Filipović et al., 2005). The underground karst forms are characterized by a large number and great diversity of caves and caverns, of which many are protected due to their scientific and cultural relevance and importance.

Caves are not only unique natural monuments in terms of geological structure and complexity, but also represent a unique habitat for a large number of organisms such as viruses, bacteria, fungi, lichen, algae, protozoa, plants and animals (Falasco et al., 2014). Phototrophic microorganisms can easily be found at cave entrances illuminated by direct or indirect sunlight and as lampenflora in areas near artificial lights, usually associated with various heterotrophic microorganisms, predominantly bacteria and fungi, also common in the inner, non-illuminated parts of the cave (Mulec and Kosi, 2008; Czerwik-Marcinkowska, 2013). Various colorations on speleothems, precipitates, corrosion residues, structural changes, and biofilms represent evidence of a microbial community (Ogórek et al., 2016).

Little is known about the microbiota of Serbian caves (Popović et al., 2015), unlike many other European countries: Spain (Martinez and Asencio, 2010; Roldán and HernándezMariné, 2009; Urzì et al., 2010; Busquets et al., 2014), France (Borderie et al., 2011, 2014; Bastian and Alabouvette, 2009), Italy (Cennamo et al., 2012; Giordano et al., 2000), Poland (Czerwik-Marcinkowska and Mrozińska, 2009, 2011; Czerwik-Marcinkowska, 2013; Ogórek et al., 2013; Pusz et al., 2014), Slovenia (Klemenčić and Vrhovšek, 2005; Mulec and Kosi, 2008; Mulec et al., 2008, 2012), Greece (Lamprinou et al., 2009, 2012, 2014; Pantazidou and Roussomoustakaki, 2005), Czech Republic (Poulíčková and Hašler, 2007), Turkey (Selvi and Altuner, 2007), and Russia (Mazina and Maximov, 2011). We investigated cyanobacterial, algal, and fungal

\footnotetext{
* Corresponding Author: spopovic.bio@gmail.com

${ }^{1}$ University of Belgrade, Scientific Institution, Institute of Chemistry, Technology and Metallurgy, Department of Ecology and Technoeconomics, 11000 Belgrade, Serbia

${ }^{2}$ University of Belgrade, Faculty of Biology, 11000 Belgrade, Serbia

${ }^{3}$ University of Belgrade, Faculty of Mining and Geology, 11000 Belgrade Serbia
} 
diversity in three karst caves in Serbia and related diversity to the environmental factors of light, temperature, and relative humidity and how these factors contribute to colonization by microorganisms.

\section{Materials And Methods}

\section{Sampling Sites and Sampling Procedure}

Ribnička Cave (RIB) (Fig. 1a) is situated in the northwestern part of Serbia, in the valley of the river Ribnica, south of Mionica $\left(44^{\circ} 12^{\prime} 20.27^{\prime \prime} \mathrm{N}, 20^{\circ} 5^{\prime} 32.59^{\prime \prime} \mathrm{E}\right)$. The gorge through which Ribnica River flows is constructed of Lower and Upper Cretaceous and Lower Triassic limestone. The cave entrance is $25 \mathrm{~m}$ wide and $12 \mathrm{~m}$ high and only $1 \mathrm{~m}$ above the riverbed, and the total length of the cave is $127 \mathrm{~m}$. From the main chamber, several short galleries diverge (Đurović, 1998). Because of the dimensions of the cave entrance and the main hall, the microclimate of the cave is heavily influenced by seasonal and daily fluctuations of outside climatic factors, primarily temperature.

Hadži Prodanova Cave (HP) (Fig. 1b) is located in the upper part of the Rašćanska River, $7 \mathrm{~km}$ from Ivanjica $\left(43^{\circ} 37^{\prime} 38.78^{\prime \prime} \mathrm{N}, 20^{\circ} 14^{\prime} 25.30^{\prime \prime} \mathrm{E}\right)$, in fissured Triassic limestones. This cave is a spacious form of underground karst topography and consists of an entrance channel, the central hall, and radiating lateral canals, with a total length of about $420 \mathrm{~m}$. The cave entrance is narrow and tall, about 5 to $6 \mathrm{~m}$ high and approximately $2 \mathrm{~m}$ wide at the beginning, then slightly narrows and continues to the spacious central hall. The cave is very dry, and only dripping water makes it hydrologically active (Đurović, 1998).

The Rćanska Caves (RC) are located on the left side of the Rćanska River, in the Dragačevo territory $\left(43^{\circ} 44^{\prime} 2.70^{\prime \prime} \mathrm{N}\right.$, $20^{\circ} 14^{\prime} 29.37^{\prime \prime} \mathrm{E}$ ), and these partly explored underground karst forms consist of Velika, Suva, and Slepa Caves and Bezdan Pit, which are composed of mostly massive Upper Cretaceous limestone, with the total length of the canals being about 750 $\mathrm{m}$. The upper part of Velika Cave, with a total length of about $380 \mathrm{~m}$ (Fig. 1c), has a cascading elevation, while the lower part is composed of three levels of galleries, the main canyon with a cascading rocky floor, the hydrologically active level that ends in a siphon, and a dry, hydrologically inactive level (Đurović, 1998). The sampling was conducted at the entrance of lower part of Velika Cave. This entrance is approximately $13 \mathrm{~m}$ wide and $17 \mathrm{~m}$ high. Since the investigated caves are still not open for tourists, there are no anthropogenic activities that may have affected the cave's ecosystems.

For algological and mycological analyses, seven sampling sites were chosen in Ribnička, while five sampling sites were selected in Hadži Prodanova and Rćanska. The locations of each sampling site near the cave entrance are shown in Fig. 1. All samples, with the exception of samples from sampling sites RC2 and RIB6, were collected from the cave walls where variously colored biofilms were formed. Sampling site RC2 was located on the horizontal surface of a large stone in the middle of the cave on which the mud deposits were observed, while sampling site RIB6 was on the cave floor.

Light intensity, temperature, and relative humidity were measured using the DMV 1300 Luxmeter, Velleman, Belgium and Temperature Humidity Meter, Extech, USA. These parameters were measured three times at each sampling site, and for each parameter, the mean values and standard errors were calculated.

\section{Algological and Mycological Analyses}

Samples for algological analyses were taken directly from the stone substrata using a non-destructive, adhesive-tape method (Gaylarde and Gaylarde, 1998; Urzì and de Leo, 2001) and by scraping the biofilm with a flame-sterilized scalpel. Afterward, the samples were stored in labeled sterile polyethylene bags and transported on ice until laboratory processing. The part of the scraped material was mixed with a drop of glycerol, and it and the adhesive strips were directly observed using the light microscope Zeiss Axio-Imager M.1 with software AxioVision 4.8. Algae and cyanobacteria were identified using the appropriate literature: John et al. (2003), Komárek and Anagnostidis (1998; 2005), Komárek (2013), Komárek and Fott (1983), Krieger and Gerloff (1962), Hofmann et al. (2013), and Starmach (1972).

For mycological analysis, five samples were collected from each of the sampling sites by swabbing the stone surfaces with sterile cotton swabs. After sampling, swabs were put in sterile polyethylene bags until laboratory processing. In laboratory conditions, swab samples were diluted in $10 \mathrm{~mL}$ sterile, deionized water and shaken steadily for 10 minutes. Aliquots of $1 \mathrm{~mL}$ prepared suspension were inoculated onto dichloran 18\% glycerol agar (DG18) and malt extract agar (MEA), both with antibiotics added to suppress bacterial growth. Chloramphenicol in the concentration of 0.1 $\mathrm{g} \mathrm{L}^{-1}$ was added to DG18 medium, while streptomycin (500 $\mathrm{mg} \mathrm{L}^{-1}$ ) was added to MEA (Samson et al., 2010). Procedures were done in triplicate. The inoculated plates were then incubated in dark conditions for seven days at $25{ }^{\circ} \mathrm{C}$ (Memmert Incubator UE500). Pure cultures of each isolate were obtained via single conidial transfer of primary isolates to the following nutrient media: Creatine sucrose agar (CREA), Czapek Yeast extract agar (CYA), DG18, Dichloran Rose Bengal Chloramphenicol agar (DRYES), MEA, Oatmeal agar (OA), and Potato Carrot Agar (PCA). After an incubation period of seven days, fungi were identified based on colony macromorphology and microscopic features of fungal reproductive structures using a stereomicroscope (Stemi DV4, Zeiss) and light microscope (Carl Zeiss Axio Imager M.1 with software AxioVision 4.8). Fungal isolates were identified to the species or genus level using the following dichotomous keys: Bensch et al. (2012), Ellis (1971), Ellis and Ellis (1997), García et al. (2006), Rapper and Fennel (1965), Samson et al. (2010), Samson and Varga (2007), Watanabe (2010), and Woudenberg et al. (2013). 


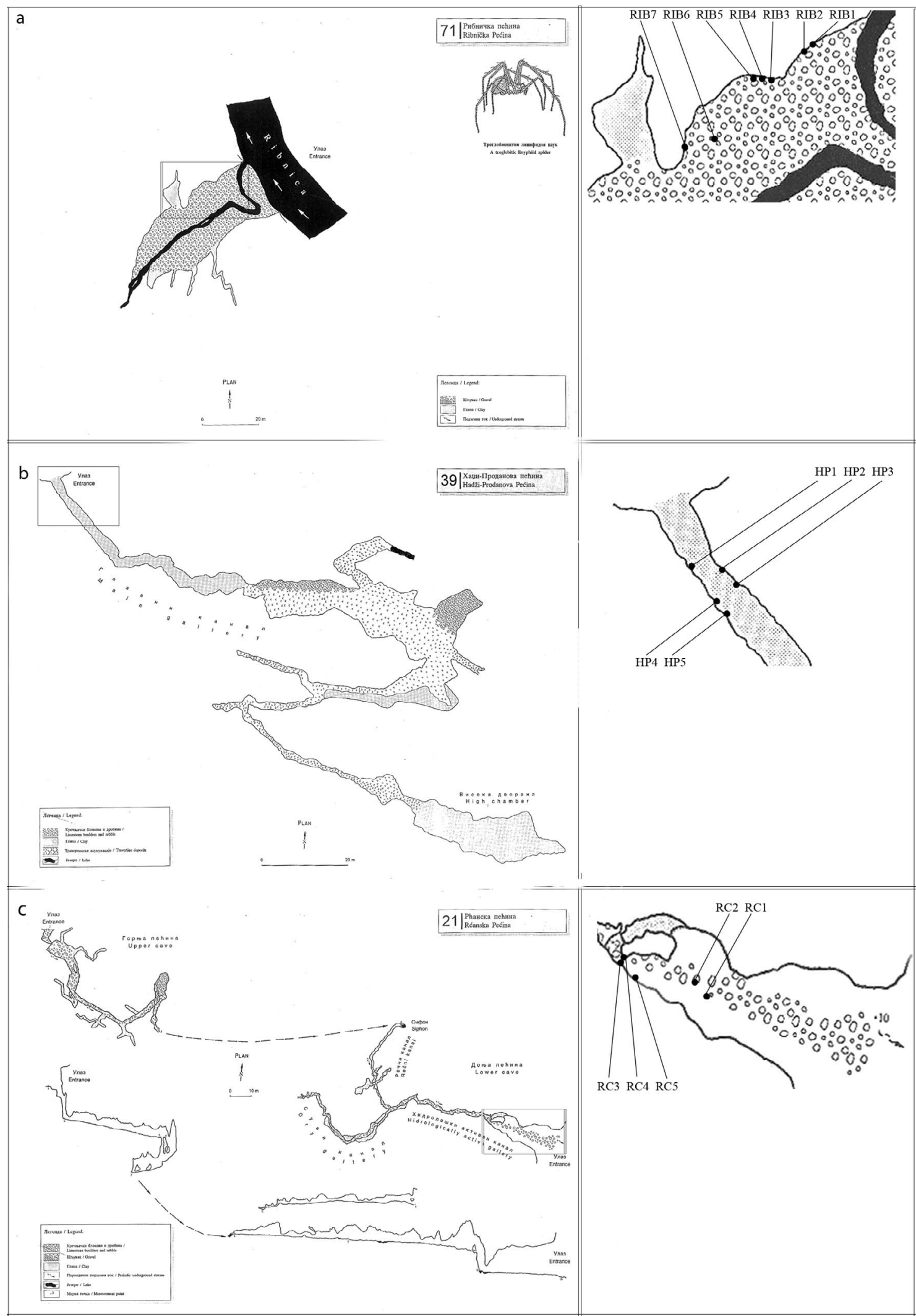

Figure 1. Maps of the three investigated caves with sampling sites near the entrance of each cave: a-Ribnička (RIB1RIB7), b-Hadži Prodanova (HP1-HP5), and c-Rćanka Caves (RC1-RC5). The sampling sites had the following distances from the cave entrances: RIB1, 8 m; RIB2, 9 m; RIB3, 13 m; RIB4, 13.5 m; RIB5, 14 m; RIB6, 22 m; RIB7, 26 m; HP1, 5 m; HP2, 6 m; HP3, 7 m; HP4, 7 m; HP5, 8 m; RC1, 22 m; RC2, 24 m; RC3, 34 m; RC4, 34 m; RC5, 30 m. 
S. Popović, G. Subakov Simić, M. Stupar, N. Unković, O. Krunić, N. Savić, and M. Ljaluević Grbić

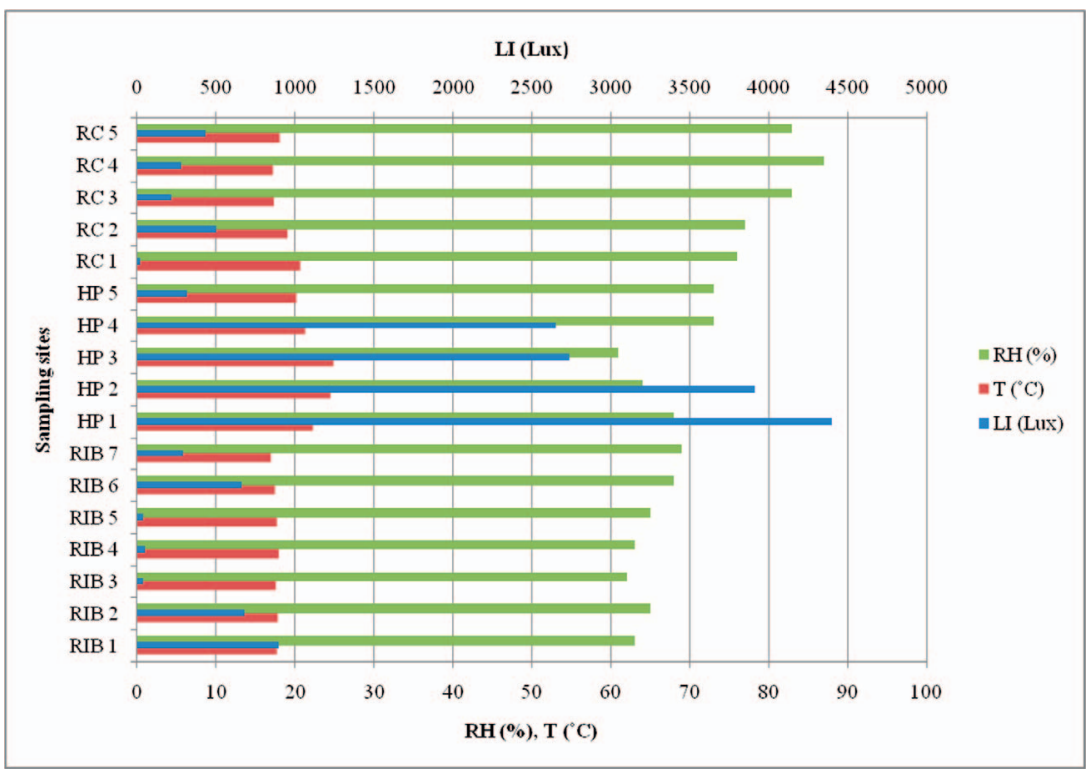

Figure 2. Measured physical parameters: light intensity (LI in Lux), temperature ( $T$ in $\left.{ }^{\circ} \mathrm{C}\right)$, and relative humidity (RH \%) at sampling sites from Ribnička (RIB1-RIB7), Hadži Prodanova (HP1-HP5), and Rćanska (RC1-RC5) caves.

\section{Determination of Chlorophyll-a, And Biofilm CONTENT}

A round metal matrix covering a surface of $3.14 \mathrm{~cm}^{2}$ was used to mark the surface on stone substrata from which the two biofilm samples were scraped for chlorophyll-a extraction and determination of the water content and content of inorganic/organic matter in biofilm samples.

Stone surfaces on which the metal matrix was applied were smooth and had minor imperfections. Scraped samples were kept in sterile polyethylene bags, and upon the arrival in the laboratory, samples were immediately prepared for the chlorophyll-a extraction. The biofilm samples were weighted and boiled in $20 \mathrm{~mL}$ of $100 \%$ ethanol. After homogenization, the samples were filtered, and the absorbance of the filtrate was measured before and after acidification at $665 \mathrm{~nm}$ and 750 $\mathrm{nm}$ on the spectrophotometer (Cecil CE 2501). The chlorophyll-a content was determined using the formula described in the study by Popovic et al. (2015), and was expressed as $\mu \mathrm{g}$ Chl-a $\mathrm{cm}^{-2}$.

Samples for the determination of the water content were kept in a sealed container to avoid water evaporation until their arrival at the laboratory. The water content and organic/ inorganic matter in the biofilm samples expressed in percent and $\mathrm{mg} \mathrm{cm}^{-2}$ were determined based on the difference in sample weight before and after drying at $105{ }^{\circ} \mathrm{C}$ and ashing at $550{ }^{\circ} \mathrm{C}$ The difference in biofilm weight between fresh samples and those dried at $105{ }^{\circ} \mathrm{C}$ gave the water content of the biofilm, while the difference between the weights at 105 ${ }^{\circ} \mathrm{C}$ and $550{ }^{\circ} \mathrm{C}$ was organic matter. The residue remaining at $550{ }^{\circ} \mathrm{C}$ was the inorganic part of the biofilm.

\section{Statistical AnAlysis}

Two redundancy analyses were performed using the program CANOCO for Windows, Version 5.0 (Ter Braak and Šmilauer, 2012). The first RDA analysis was performed to examine the potential effects of measured environmental variables on cyanobacterial, algal, and fungal community with the cave used as a supplementary variable. For project data, presence/absence of all recorded taxa was used as a measure. Then each taxon was assigned to a taxonomic group (Cyanobacteria, Chlorophyta, Bacillariophyta, or fungi). In further analysis, we used these groups instead of individual taxa. The measured environmental variables temperature, relative humidity, and light intensity were submitted to the interactive forward selection, in which the statistical significance of each variable was tested by the Monte Carlo permutation test at a cutoff point of $\mathrm{P}=0.05$. RDA with the option 'center and standardize' was used. The main goal was to show if some groups are influenced by any of the measured environmental factors. The second RDA analysis, with cave as an explanatory variable, was performed to demonstrate the preference of microorganism groups for a certain cave, as well as the proportion of documented taxa found in every cave.

\section{RESULTS}

Light intensity varied from the lowest value of 21.5 Lux, measured at sampling site RC1, to the highest value of 4400 Lux, measured at sampling site HP1. The highest temperature was measured at HP3 $\left(24.9^{\circ} \mathrm{C}\right)$ and the lowest at RIB7 (16.9 $\left.{ }^{\circ} \mathrm{C}\right)$. The lowest relative humidity was measured at HP3 (61\%), and the highest at RC4 (87\%) (Fig. 2). The highest 


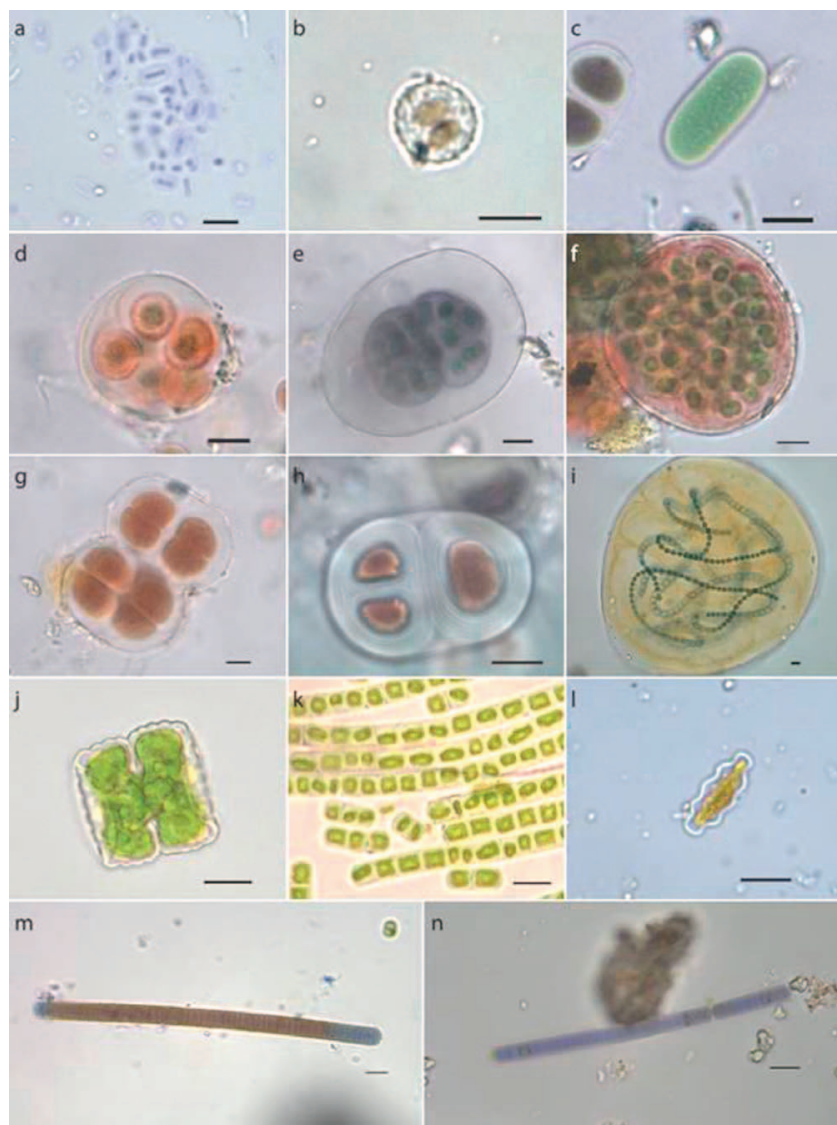

Figure 3. Micrographs of some documented cyanobacteria and algae in biofilm samples from Ribnička (a Aphanothece caldariorum; b - Asterocapsa sp.; c Cyanothece aeruginosa; d - Gloeocapsa sanguinea; e Gloeocapsa alpina; h - Chroococcus ercegovicii), from Hadži Prodanova (f - Gloeocapsa novacekii; g Chroococcus sp.; i - Nostoc commune; m - Oscillatoria sancta), and from Réanska (j - Cosmarium rectangulum; k Klebsormidium flaccidum; l - Luticola nivalis; n Phormidium sp.) caves. Scale bars $10 \mu \mathrm{m}$.

values of light intensity and temperature were measured in Hadži Prodanova. Measured relative-humidity values were obviously lowest in Ribnička, where cyanobacteria prevailed, and some sampling sites in Hadži Prodanova. The differences in the measured physical parameters were easily visible when the data from all localities were compared, but there were no significant differences among the sampling sites in any one cave, except for light intensity.

The two methods of biofilm sampling for cyanobacterial and algological analyses, non-destructive adhesive tape and scraping the biofilm with flame-sterilized scalpels, were found to support each other and contributed to a more detailed identification of taxa in biofilm. During the survey in the investigated caves, Cyanobacteria (Table 1) and algae (Chlorophyta and Bacillariophyta) (Table 2) were documented. The highest number of documented taxa belonged to Cyanobacteria, with chroococcalean taxa prevailing and
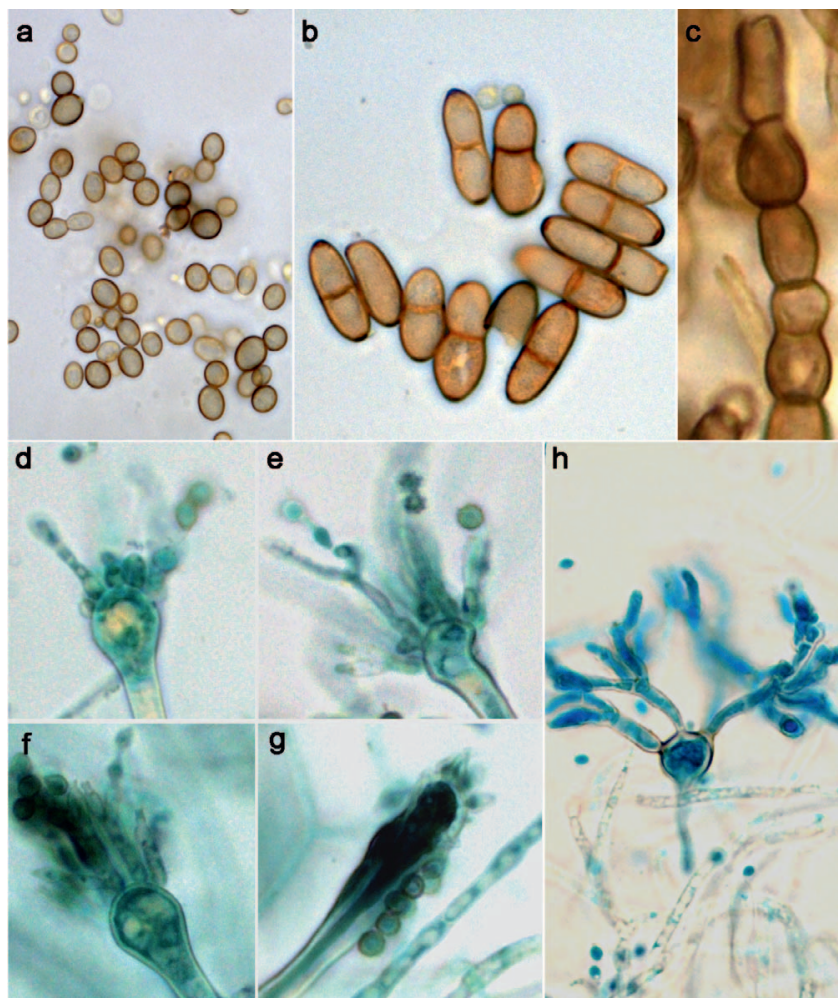

Figure 4. Culturable fungi (seven days, malt extract agar) from Hadži Prodanova, Rćanska, and Ribnička caves: a. black yeast cells; b. didimospores of Cladosporium-like dematiaceous Hyphomycetes; c. unbranched chain of microcolonial fungi meristematic cells; d-g. aberant conidiogenus apparatus in Aspergillus sect. Nidulantes culture; h. microciclic conidiation in Penicillium sp. culture.

species of the genus Gloeocapsa being the most diverse. Oscillatoriales and Nostocales were present to a lesser extent. Most of the cyanobacteria that were documented in these three caves were aerophytic taxa, while Chlorophyta and Bacillariophyta had aerophytic and freshwater representatives. Some of the documented taxa are shown in Figure 3. Many cyanobacterial and algal taxa were documented only in one of the caves. Aphanothece saxicola, Desmococcus olivaceus, Hantzschia amphioxys and Nitzschia sp. were documented in all three, while Aphanocapsa muscicola, Chroococcus sp., Chroococcus turgidus, Gloeocapsa biformis, Gloeocapsa reicheldtii, Gloeocapsa violascea, Leptolyngbya foveolarum, Oscillatoria sancta, Nostoc commune, Trochiscia granulata and Luticola nivalis were found in two caves.

In all investigated samples, 27 different fungal morphotypes, including filamentous fungi, yeasts (Fig. 4a), and microcolonial fungi (Fig. 4c) were isolated. A list of identified fungi is presented in Table 3. The majority of documented fungi were Ascomycetes or Zygomycetes. However, the plant pathogen Rhizoctonia s. 1. (teleomorph: Thanatephorus sp.) was the only member of Basidiomycetes documented in this study; it was isolated from walls of Hadži Prodanova. Microcolonial fungi, 
S. Popović, G. Subakov Simić, M. Stupar, N. Unković, O. Krunić, N. Savić, and M. Ljaljević Grbić

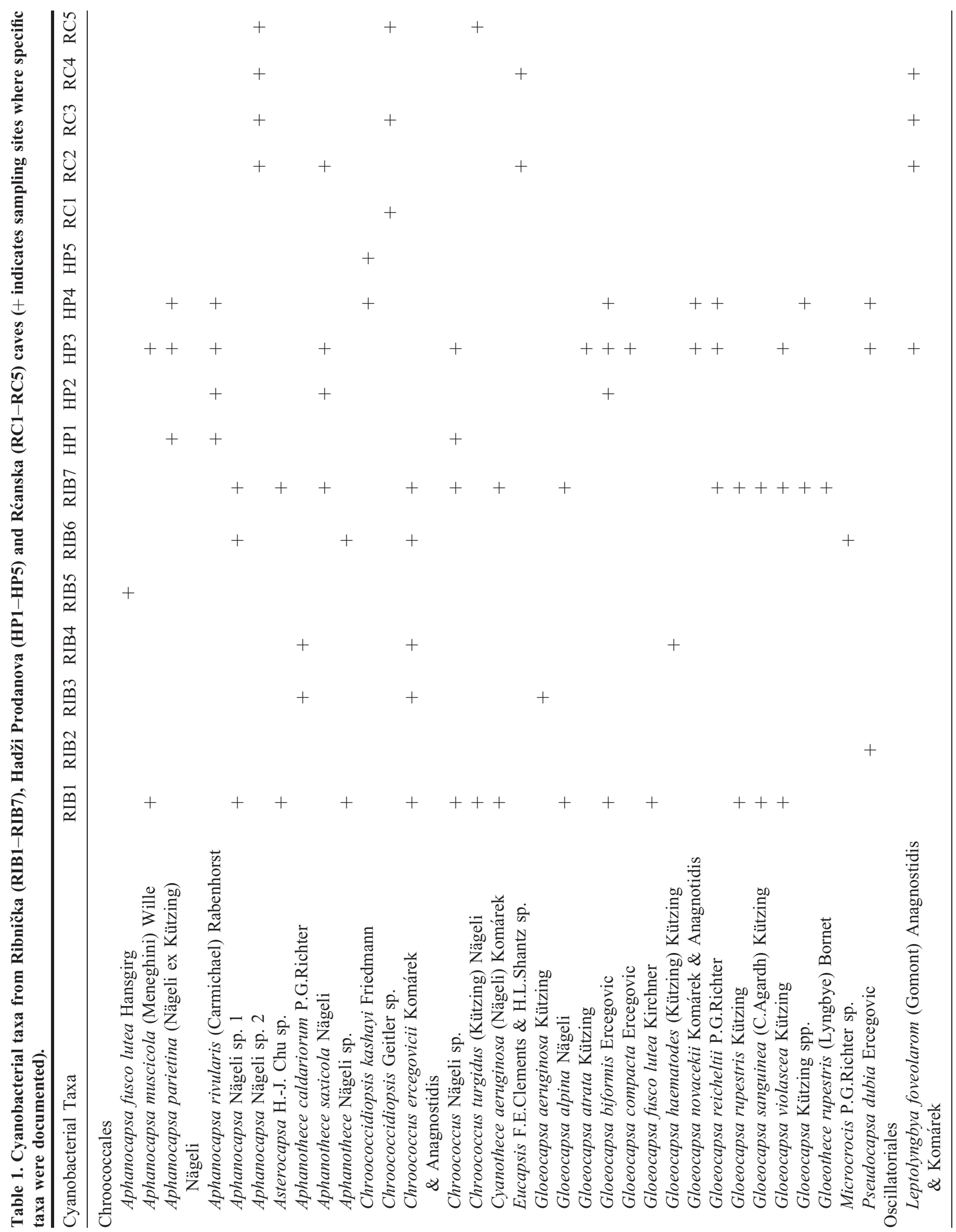




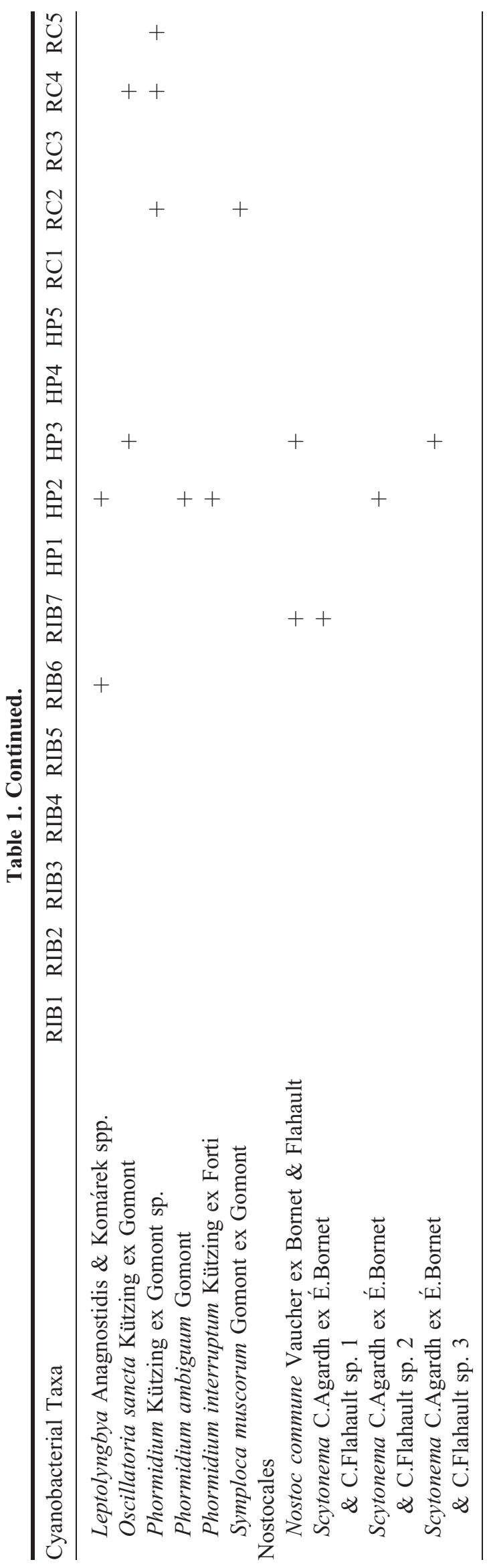

well-known as rock-inhabiting fungi, were frequently encountered in all studied caves (Isola et al., 2016).

During laboratory cultivation, microscopic analyses revealed the presence of atypical fungal structures, such as aberrant conidial apparatus in Aspergillus sp. sect. Nidulantes (Fig. 4d, g) and microcyclic conidiation in one Penicillium isolate (Fig. 4h).

Interactive forward selection revealed that relative humidity was the only measured environmental variable that was statistically significant (Fig. 5A). The redundancy analysis including humidity as an explanatory variable and Cyanobacteria, Chlorophyta, Bacillariophyta, and fungi as response data showed that relative humidity was positively correlated with the first RDA axis $(r=0.7067)$, which explained $23.99 \%$ of the total variance in our data. Thus, the first axis represented the variation in cyanobacterial, algal, and fungal assemblage explainable by the humidity variable, and the second vertical axis represented a part of residual variation that was not explained by that variable, which suggested that there might also have been other environmental factors influencing the distribution of these groups of microorganisms. Still, the effect of humidity was significant, as confirmed by the result of the Monte Carlo permutation test ( $\mathrm{F}=4.6, p=0.0075)$. Bacillariophyta and Chlorophyta showed positive correlations with the first RDA axis, which showed that most preferred places are those with higher levels of air humidity. On the other hand, cyanobacteria showed a negative correlation with the first RDA axis, as they were mostly found in places with lower humidity. Fungi showed a slightly negative, almost nonexistent correlation with the first RDA axis, but a highly positive correlation with the second RDA axis, meaning that other factors affected the appearance and development of fungi in a certain locality. Cyanobacteria also showed a correlation with the second axis, but it was negative.

The second redundancy analysis (Fig. 5B) showed that the caves were separated along the first axis, as were taxonomic groups. Cyanobacteria and fungi were placed on the left side of the ordination diagram (they were mostly found in Hadži Prodanova and Ribnička), while Chlorophyta and Bacillariophyta were placed on the right side of the ordination diagram (mostly found in Rćanska). In addition, each group is represented as a pie symbol, in which the proportion of documented taxa found in every cave can be seen. Cyanobacterial taxa, with the most numerous being from the order Chroococcales, were predominant in Ribnička and Hadži Prodanova, while in Rćanska smaller number of taxa were recorded. The fungi showed the same pattern. On the other hand, Chlorophyta and Bacillariophyta were mostly documented in samples from Rćanska.

The lowest values of chlorophyll-a content, expressed as $\mu \mathrm{g}$ Chl-a $\mathrm{cm}^{-2}$, were documented at sampling sites RIB2 and RIB5, where few cyanobacterial and algal taxa were found. Two sampling sites that were on a horizontal substrate (RIB6 and RC2) had the highest concentrations of chlorophyll-a (Fig. 6). The content of organic matter expressed as $\mathrm{mg} \mathrm{cm}^{-2}$ was also the highest at RIB6 and RC2, and the highest content of 
S. Popović, G. Subakov Simić, M. Stupar, N. Unković, O. Krunić, N. Savić, and M. Ljaljević Grbić

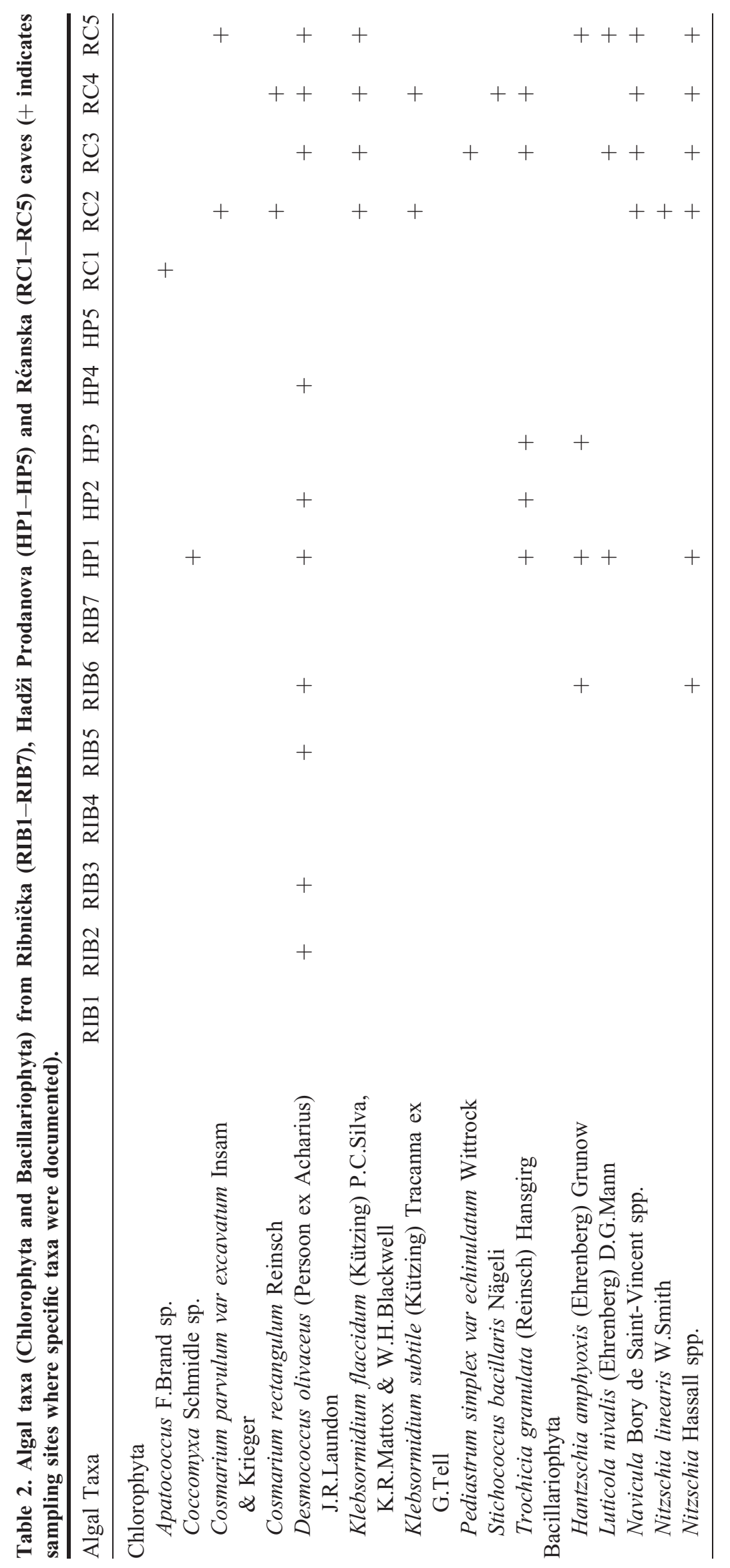


Table 3. Identified culturable fungi in biofilm samples from Ribnička (RIB1-RIB7), Hadži Prodanova (HP1-HP5) and Rćanska (RC1-RC5) caves and methods that are used for their identification.

Fungal Isolates

Source of Isolation

Identification Method

Alternaria spp. and Alternaria like genera

(3 morphotypes)

Alternaria Nees sp. 1 sect. Alternata

Alternaria Nees sp. 2 sect. Alternata

Aspergillus spp. (6 morphotypes)

Aspergillus P. Micheli sp. 1. sect. Usti

Aspergillus P. Micheli sp. 2. sect.

Nidulantes

Aspergillus P. Micheli sp. 3. sect. Nigri

Aspergillus P. Micheli sp. 4. sect.

Clavati

Aspergillus P. Micheli sp. 5. sect. Terei

Aspergillus P. Micheli sp. 6. sect. Circummdati

Cladosporium spp. and Cladosporium like genera (4 morphotypes)

Cladosporium cladosporioides (Fresen.)

G.A. de Vries s. lat

Cladosporium sphaerospermum Penz. s. lat

Cladosporium Link spp.

Other Hyphomycetes

Aureobasidium pullulans (de Bary)

G. Arnaud

Botrytis cinerea Pers.

Epicoccum nigrum Link.

Paecilomyces variotii Bainier

Humicola Traaen sp.

Penicillium Link spp. (3 morphotypes)

Periconia bysoides Pers.

Zygomycetes (3 morphotypes)

Mucor Micheli: Fr. spp.

Rhizopus stolonifer (Ehrenb.) Vuill.

Basidiomycetes

Rhizoctonia DC. s. lat
HP1

RIB7

HP3

HP2, HP3, HP4

RIB7, HP1, HP3, HP4, RC5

HP4, HP5

HP1, HP5

HP4

RIB2, RIB6, RIB7, HP1, HP5, RC2

$\mathrm{RC} 3$

RIB1, RIB6, RC2, HP3

RIB2, RIB5, HP3, RC3

RIB1, RIB2

RIB1, RIB5, RIB7, HP1, HP2, HP5

$\mathrm{HP} 5, \mathrm{RC} 3$

$\mathrm{RC} 2, \mathrm{RC} 3, \mathrm{RC} 4$

HP4, HP5, RIB1, RIB4, RIB5, RIB6, RIB7, HP3, HP4, RC1, RC4 HP3

RC3, RC4

HP4, HP5
PCA, DRYES, DG18 (Woudenberg et al., 2015)

PCA, DRYES, DG18 (Woudenberg et al., 2015)

CYA, MEA, DG18 (Rapper and Fennel, 1965; Samson and Varga, 2007)

CYA, MEA, DG18 (Rapper and Fennel, 1965; Samson and Varga, 2007)

CYA, MEA, DG18 (Rapper and Fennel, 1965; Samson and Varga, 2007)

CYA, MEA, DG18 (Rapper and Fennel, 1965; Samson and Varga, 2007)

CYA, MEA, DG18 (Rapper and Fennel, 1965; Samson and Varga, 2007)

CYA, MEA, DG18 (Rapper and Fennel, 1965; Samson and Varga, 2007)

MEA, DG18, DRYES (Bensch et al., 2012)

MEA, DG18, DRYES (Bensch et al., 2012)

MEA, DG18, DRYES (Bensch et al., 2012)

MEA, OA, DG18 (Samson et al., 2010)

MEA, OA, DG18 (Samson et al., 2010)

MEA, OA, DG18 (Samson et al., 2010)

MEA, OA, DG18 (Samson et al., 2010)

MEA, OA, DG18 (Watanabe, 2010)

CYA, MEA, CREA (Pitt, 1979; Samson et al., 2010)

MEA, OA (Ellis, 1971; Ellis and Ellis, 1997)

MEA, OA, DG18 (Samson et al., 2010)

MEA, OA, DG18 (Samson et al., 2010)

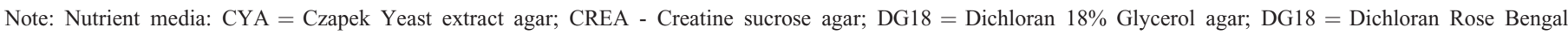
Chloramphenicol agar; $\mathrm{MEA}=$ Malt extract agar; $\mathrm{OA}=$ Oatmeal agar; $\mathrm{PCA}=$ Potato Carrot Agar

inorganic matter was found at RC2 and RIB1. The water content was high at RC2, RIB3, RIB6, and RC4. In general, the highest biomass was observed at RIB6 and RC2. The lowest values of all three biofilm parameters were recorded at RIB5, HP4, and RC3. The table depicting the measured biofilm parameters in percentages was included to display the relationship of every measured component in each biofilm 18 - Journal of Cave and Karst Studies, April 2017 sample (Table 4). The water was the main biofilm constituent at RIB3, RIB7, HP3 and RC4.

\section{DisCUSSION}

Cyanobacteria and algae (with green algae and diatoms as the most important (Falasco et al., 2014)), are the most 

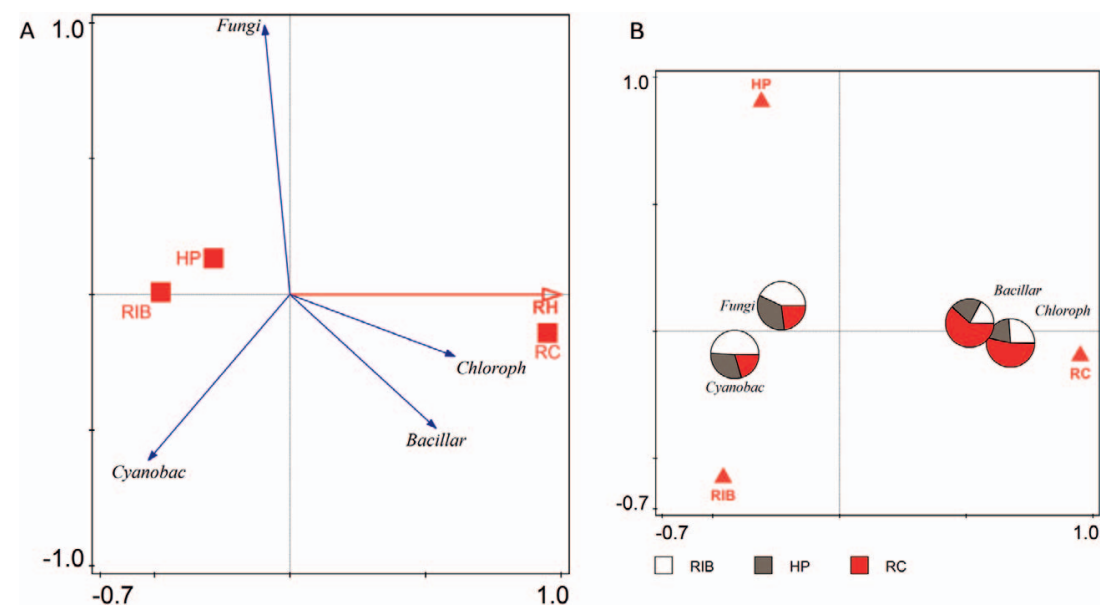

Figure 5. A - Redundancy analysis biplot ordination on the basis of the measured environmental variable relative humidity and cyanobacterial, algal (Chlorophyta and Bacillariophyta), and fungal community with cave as a supplementary variable. B - Redundancy-analysis biplot ordination of cyanobacteria, algae (Chlorophyta and Bacillariophyta), and fungi with locality as an explanatory variable. Each group was represented as a pie symbol, in which the proportion of documented taxa found in every cave can be seen. Caves: Ribnička RIB, Hadži Prodanova HP, and Rćanska RC.

common phototrophic constituents of cave ecosystems (Mulec et al., 2008). Cyanobacteria and green algae are considered the pioneer colonizers of many exposed surfaces, followed by various heterotroph such as bacteria and fungi. These organisms play an important role in biofilm genesis (Falasco et al., 2014). Cyanobacteria prevail compared to other microorganisms (Czerwik-Marcinkowska, 2013; Mulec et al., 2008; Selvi and Altuner, 2007; Mulec and Kosi, 2008; Mazina and Maximov, 2011), especially in cave entrances (Mulec and Kosi, 2008). Most of the documented cyanobac-

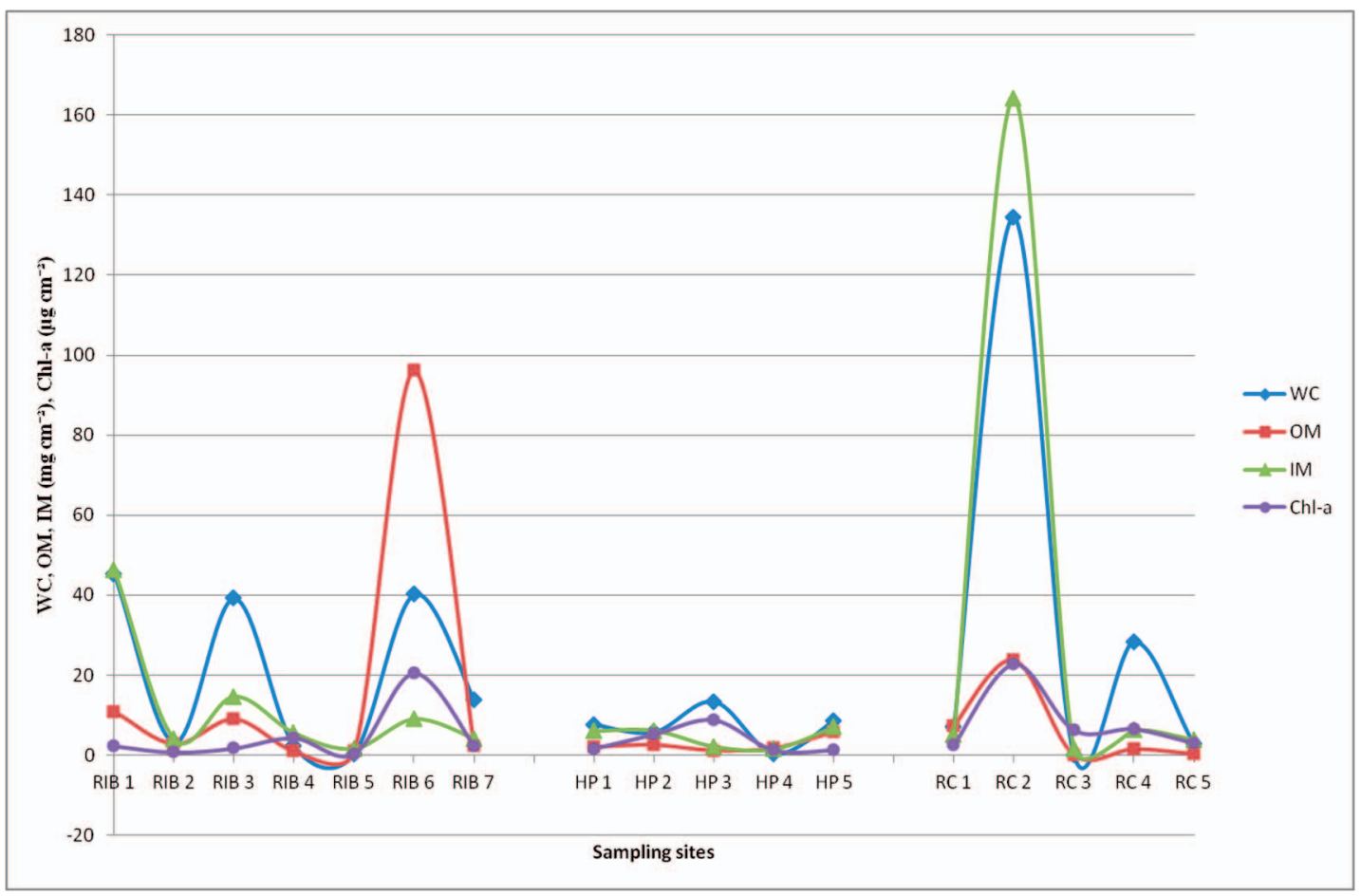

Figure 6. Chlorophyll-a content (Chl-a) expressed as $\mu \mathrm{g} \mathrm{cm}^{-2}$ water content (WC) and content of organic/inorganic matter $(\mathrm{OM} / \mathrm{IM})$ expressed as $\mathrm{mg} \mathrm{cm}^{-2}$ determined in biofilm samples from Ribnička (RIB1-RIB7), Hadži Prodanova (HP1HP5), and Réanska (RC1-RC5) caves. 
Table 4. Water content (WC) and content of organic/inorganic matter (OM/IM), represented as percentages, determined in biofilm samples from Ribnička (RIB1-RIB7), Hadži Prodanova (HP1-HP5) and Rćanska (RC1-RC5) caves.

\begin{tabular}{lrrrrrrrrrrrrrrrrr}
\hline $\begin{array}{l}\text { Biofilm } \\
\text { Content }\end{array}$ & RIB1 & RIB2 & RIB3 & RIB4 & RIB5 & RIB6 & RIB7 & HP1 & HP2 & HP3 & HP4 & HP5 & RC1 & RC2 & RC3 & RC4 & RC5 \\
\hline WC & 44.2 & 32.3 & 62.4 & 25.9 & 11.1 & 27.6 & 68.3 & 49.0 & 40.0 & 80.8 & 9.1 & 40.3 & 36.1 & 41.7 & 2.0 & 78.8 & 40.9 \\
OM & 10.6 & 27.7 & 14.3 & 10.7 & 33.3 & 66.2 & 11.3 & 12.9 & 17.6 & 6.7 & 50.0 & 27.0 & 37.5 & 7.4 & 2.0 & 4.1 & 4.1 \\
IM & 45.2 & 40.0 & 23.3 & 63.3 & 55.6 & 6.2 & 20.5 & 38.2 & 42.4 & 12.5 & 40.9 & 32.7 & 26.4 & 50.9 & 96.0 & 17.2 & 55.0 \\
\hline
\end{tabular}

teria from the caves we investigated were typical aerophytic taxa. Coccoid forms of cyanobacteria were the most common, followed by Oscillatoriales and then Nostocales (Lamprinou et al., 2009, 2012, 2014; Martinez and Asencio, 2010; Pantazidou and Roussomoustakaki, 2005). Most coccoid cyanobacteria produce thick mucilaginous sheaths by which they attach to the substrates to help further colonization by other microorganisms. However, Oscillatoriales, which are usually less present, can form hormogonia that help them colonize new sites in the caves (Pantazidou and Roussomoustakaki, 2005). The most common genus found during this survey, Gloeocapsa, has been reported in various habitats with many different ecological characteristics, indicating its tolerance to a wide range of environmental conditions (Cennamo et al., 2012). Chlorophyta and Bacillariophyta are usually found together with cyanobacteria (Czerwik-Marcinkowska, 2013; Lamprinou et al., 2012; Cennamo et al., 2012; Selvi and Altuner, 2007; Mazina and Maximov, 2011; Klemenčić and Vrhovšek, 2005). Among green algae, unicellular forms tend to dominate (Roldán and Hernández-Mariné, 2009). These groups are represented by both aerophytic and freshwater taxa. In addition, aquatic taxa of Bacillariophyta can be present, but they usually show some morphological modifications (Falasco et al., 2014).

Even though cyanobacteria prevail in general, they are not always predominant; in our case, Cyanobacteria, Chlorophyta and Bacillariophyta were not equally distributed.

The temperature and relative humidity did not show large differences among the sampling sites in one cave due to the sampling sites' proximity to each other, but light intensity showed differences among all three examined caves; even small differences can have an immense impact on the ecosystem. The light intensity depended on factors like the distance from the entrance, exposure of the sampling site, rock depressions, and the presence of bigger cavities. Light intensity and other factors are also affected by the size and orientation of the cave entrance, as well as by the presence or absence of vegetation in front of the entrance. The highest temperature was usually measured at sampling sites that were closest to the cave entrance or at the entrance. The highest measured values of temperature and light intensity were recorded in Hadži Prodanova, which was probably due to the specific shape of the narrow and tall entrance facing south, allowing more light to reach cave walls. The highest humidity values were mostly measured at sampling sites that were farthest from the cave entrances, at places that were well shaded, and, as was the case with Rćanska, at sampling sites where running and dripping water was present. Furthermore, sampling sites in Rćanska were farther from the entrance and more isolated from external conditions compared to the other two investigated localities.

The constrained analysis of measured ecological parameters showed that only relative humidity was statistically significant. The highest humidity values were documented in Rćanska, where most of Chlorophyta and Bacillariophyta were recorded. On the contrary, the lowest humidity was documented in Ribnička and Hadži Prodanova, where Cyanobacteria were dominant. This suggests that humidity is likely an important factor in the development of specific communities in a given location. The presence of periodically available water in forms such as rain, dew, or condensation is important for the microbial colonization of rock surfaces (Whitton, 2012). However, cyanobacteria are known to produce extracellular polymeric substances (polysaccharides, proteins, lipids, and nucleic acids) that, aside from having many beneficial roles such as chelating toxic substances, serving as a nutrient reservoir, regulating calcification processes, and protecting from UV radiation, can also retain water, which is of great importance (Whitton, 2012; Falasco et al., 2014). For that reason, many cyanobacteria are very desiccation-tolerant and are able to inhabit places that are more arid compared to many other algal groups (Poulíčková and Hašler, 2007).

Chlorophyta and Bacillariophyta were recorded mainly in places with higher humidity. They dominated the entrance walls of Rćanska, especially at sampling sites RC2, 3, and 4. As mentioned, sampling site 2 was located on a horizontal plane, where mud and water accumulated. Sites 3 and 4 were characterized by the presence of dripping water, where algae from the genus Klebsormidium were mostly present. Desmococcus olivaceus, one of the most common aerophytic algae (Rindi, 2007), was one of the most frequently found algal taxa in this cave. On the other hand, Bacillariophyta were unequally distributed in all three caves. In Ribnička, they were documented only on the cave floor, inhabiting accumulated soil and mud (sampling site RIB 6). In Hadži Prodanova, most of the diatoms were found at the sampling site with highest illumination (HP1) while, in Rćanska they were present in association with Chlorophyta at the sampling site where mosses were present (RC5). The appearance of diatoms and changes in their composition were related to humidity fluctuations. In general, surfaces that are illuminated, wet, and 
characterized by the presence of mosses are richer in diatoms. Luticola nivalis and Hantzschia amphioxys are typical aerophilous diatoms that can be found in the majority of caves, and they can be considered cosmopolitan taxa. Hantzschia amphioxys, common as an epiphytic diatom, usually occurs on mosses (Falasco et al., 2014).

Aerophytic cyanobacteria and algae are significantly influenced by temperature, light, and moisture conditions (Pouličková and Hašler, 2007), but many other factors such as the input of nutrients, type and physicochemical substrate properties ( $\mathrm{pH}$, rock substance, porosity), cave morphology (size, location, dimension, orientation), and water availability affect the composition of the microbial communities and can explain the variation in species composition (CzerwikMarcinkowska, 2013; Lamprinou et al., 2012; Pantazidou and Roussomoustakaki, 2005). The importance of the substrate can be seen from the fact that the calcareous, alkaline nature of the substrate favors the proliferation of cyanobacteria where the light is adequate (Pantazidou and Roussomoustakaki, 2005).

At both sampling sites with the highest content of chlorophyll-a, a thick green biofilm containing densely packed cells of cyanobacteria and algae was present. Biofilm at RIB6 was mostly made of densely entangled Leptolyngbya sp. According to Knott et al. (2004), horizontal surfaces collect more algae than do vertical surfaces. Certain parts of biofilms from cave walls can be washed with water that periodically flows over the rocks, or it can just "fall off" from time to time. In addition, these sampling sites contained the highest amount of organic matter. Sampling sites RIB7 and HP3, which had the highest water content expressed as a percentage, also had the highest number of cyanobacterial taxa, for which extracellular polymeric substances are responsible for retaining water. The sampling site RC4 also had a high water content percent because of the presence of seeping water. The correlation between chlorophyll-a content and light intensity was not observed $(r=-0.061)$.

Fungal spores and hyphal fragments are introduced into caves through the air and water flow (Hsu and Agoramoorthy, 2001). Likewise, trogloxenes, animals that live within caves but periodically come out to feed, are known carriers of plant and animal remains, organic debris, and fungal propagules. The majority of fungi isolated and identified in this survey are frequently cited as plant and leaf-litter inhabitants (members of genera Alternaria, Aspergillus, Botrytis, Cladosporium, Epicoccum, and Periconia), while fungi, represented by species of genera Humicola, Mucor, Paecilomyces, Penicillium, Rhizopus, and Rhizoctonia, are typical soil colonizers (Dix and Webster, 1995). Hence the majority of identified fungi can be considered transients in cave habitats (Vanderwolf et al., 2013). On the other hand, yeast-like micro-colonial fungi in the form of torulose, branched hyphae and meristematic cells, documented via microscopic analyses of cultured fungi in all studied caves, are nowadays recognized as typical rock-inhabiting fungi (Ruibal et al., 2009). So this phylogenetically diverse group of melanized ascomycetes can be thought of as an autochthonous or residential fungal community in caves.

The establishment of fungal communities in cave habitats is mostly dependent on the availability of nutrients. The highest number of culturable fungi were isolated from the sampling sites where very developed biofilms were observed and high biomass was documented, such as RIB1. On the other hand, our recorded micro-environmental conditions of temperature, light intensity, and relative humidity were shown to not influence the distribution of fungi at sampling sites. However, Sterling and Lewis (1998) reported that these micro-environmental conditions were critical for the secondary release of spore and fungal growth within the caves and heavily influenced differences in fungal communities inside and outside of caves.

During the microscopic analyses of fungal isolates, the presence of atypical structures, such as the aberrant conidiogenus apparatus in Aspergillus sp. sect. Nidulantes and microcycle conidiation in one Penicillium culture, was observed. Microcycle conidiation, the phenomena of the direct production of conidia from asexual spores without hyphal growth, bypassing the somatic phase in the normal fungal life cycle, has been described in a broad range of fungi, including the genera Acremonium, Aspergillus, Cercospora, Neurospora, Paecilomyces, Penicillium and Trichoderma (Hanlin, 1994). Presumably, morphological variances typical of microcycle conidiation and aberrant conidiophore formation are a key mechanism for survival and proliferation of mold spores of the aforementioned genera in adverse environmental conditions (Lapaire and Dunkle, 2003). Furthermore, microcycle conidiation encompasses a normal phase in the life cycle of several fungal groups, among which are rust and smut fungi, as well as other plant (e.g., Taphrinales and Calvicipitales) and insect pathogens (Entomophthorales).

\section{Conclusions}

Cyanobacteria, algae (Chlorophyta and Bacillariophyta), and fungi were examined from biofilm samples taken from the entrances of Ribnička, Hadži Prodanova, and Rćanska caves. Cyanobacteria, with chroococcalean taxa prevailing and Gloeocapsa species as the most diverse, had the highest number of documented taxa. The majority of identified fungi were Ascomycetes or Zygomycetes, with Rhizoctonia s. 1. as the only representative of Basidiomycetes. Physical parameters temperature and relative humidity did not show such big differences among sampling sites as did light intensity, which was dependent on the distance from the entrance and rock position. According to redundancy analysis and interactive forward selection that were performed on all measured environmental parameters, only relative humidity was a physical parameter that was statistically significant, meaning that it is likely an important factor influencing the development of microbial communities at different localities. Most of 
Bacillariophyta and Chlorophyta were found at places with higher relative humidity, while many cyanobacteria were found in places where lower air humidity was measured. Measured physical parameters did not have a significant influence on the distribution of fungi. The second redundancy analysis that was performed confirmed that different taxonomic groups were dominant at different caves, cyanobacteria and fungi in Ribnička and Hadži Prodanova and Chlorophyta and Bacillariophyta in Rćanska cave. Chlorophyll-a content did not show correlation with light intensity. It was highest on a horizontal surfaces where the highest content of organic and inorganic matter were recorded. Higher water content in biofilm was found in samples from which many cyanobacterial taxa were identified.

It is known that many microorganisms from biofilms, through various known mechanisms of biodeterioration, can cause substantial damage to the stone surfaces. The exploration of their diversity, especially of phototrophic components, represents a contribution to the flora of Serbia, and is also the basis for further research that will include more experimental studies in terms of the conservation of these protected sites.

\section{ACKNOWLEDGEMENTS}

This research was supported by the Ministry of Science and Technological Development, Republic of Serbia, Projects No. 176018 and No 176020 and Ministry of Agriculture and Environmental Protection of Republic of Serbia.

\section{REFERENCES}

Bastian, F., and Alabouvette, C., 2009, Lights and shadows on the conservation of a rock art cave: the case of Lascaux Cave: International Journal of Speleology, v. 38, no. 1, p. 55-60. https://doi.org/10.5038/ 1827-806X.38.1.6.

Bensch, K., Braun, U., Groenewald, J.Z., and Crous, P.W., 2012, The genus Cladosporium: Studies in Mycology, v. 72, 401 p. https://doi.org/10.1016/ S0166-0616(14)60069-5.

Borderie, F., Laurence, A.-S., Naoufal, R., Faisl, B., Geneviève, O., Dominique, R., and Badr, A.-S., 2011, UV-C irradiation as a tool to eradicate algae in caves: International Biodeterioration and Biodegradation, v. 65, p. 579-584. https://doi.org/10.1016/j.ibiod.2011.02.005.

Borderie, F., Tête, N., Cailhol, D., Alaoui Sehmer, L., Bousta, F., Rieffel, D., Aleya, L., and Alaoui Sossé, B., 2014, Factors driving epilithic algal colonization in show caves and new insight into combating biofilm development with UV-C treatment: Science of the Total Environment, v. 484, p. 43-52. https://doi.org/10.1016/j.scitotenv.2014.03.043.

Busquets, A., Fornós, J.J., Zafra, F., Lalucat, J. and Merino, A., 2014, Microbial communities in a coastal cave: Cova des Pas de Vallgornera (Mallorca, Western Mediterranean): International Journal of Speleology, v. 43, no. 2, p. 205-216. https://doi.org/10.5038/1827-806X.43.2.8.

Cennamo, P., Marzano, C., Ciniglia, C., Pinto, G., Cappelletti, P., Caputo, P., and Pollio, A., 2012, A survey of the algal flora of anthropogenic caves of Campi Flegrei (Naples, Italy) archeological district: Journal of Cave and Karst Studies, v. 74 , no. 3, p. 243-250. https://doi.org/10.4311/ 2011JCKS0194.

Czerwik-Marcinkowska, J., 2013, Observations on aerophytic cyanobacteria and algae from ten caves in the Ojców national park: Acta Agrobotanica, v. 66, no. 1, p. 39-52. https://doi.org/10.5586/aa.2013.005.

Czerwik-Marcinkowska, J., and Mrozińska, T., 2009, Epilithic algae from caves of the Krakowsko-Częstochowska upland (Southern Poland): Acta
Societatis Botanicorum Poloniae, v. 78, no. 4, p. 301-309. https://doi.org/ 10.5586/asbp.2009.040.

Czerwik-Marcinkowska, J., and Mrozińska, T., 2011, Algae and cyanobacteria in caves of the Polish Jura: Polish Botanical Journal, v. 56, no. 2, p. 203 243

Dimitrijević, M., 1974, The Dinarides: A model based on the new global tectonics, in Jankovic, S., ed., Metallogeny and Concepts of the Geotectonic Development of Yugoslavia: Belgrade, Faculty of Mining and Geology, Department of Economic Geology, p. 141-178.

Dix, N.J., and Webster, J., 1995, Fungal Ecology: London, Chapman and Hall, $549 \mathrm{p}$.

Đurović, P., ed., 1998, Speleološki atlas Srbije, posebno izdanje br. 52: Beograd, Geografski institut „Jovan Cvijić” SANU, Zavod za zaštitu prirode Srbije, Geografski fakultet u Beogradu, Biološki fakultet Univerziteta u Beogradu, 290 p. (Speleological Atlas of Serbia: Belgrade, Jovan Cvijic Geographical Institute, Serbian Academy of Sciences and Arts special issue 52, 290 p.)

Ellis, M.B., 1971, Dematiaceous Hyphomycetes: Kew, Surrey, England, Commonwealth Mycological Institute, $608 \mathrm{p}$.

Ellis, M.B., and Ellis, J.P., 1997, Microfungi on Land Plants, an Identification Handbook second edition: Slough, England, The Richmond Publishing Co. Ltd, $868 \mathrm{p}$.

Falasco, E., Ector, L., Isaia, M., Wetzel, C.E., Hoffmann, L. and Bona, F., 2014, Diatom flora in subterranean ecosystems: a review: International Journal of Speleology, v. 43, no. 3, p. 231-251. https://doi.org/10.5038/ 1827-806X.43.3.1.

Filipović, B., Krunić, O. and Lazić, M., 2005, Regionalna hidrogeologija Srbije: Beograd, Rudarsko geološki fakultet Univerziteta u Beogradu, 401 $\mathrm{p}$

García, V.G., Onco, M P., and Susan, V.R., 2006, Review. Biology and systematics of the form genus Rhizoctonia: Spanish Journal of Agricultural Research, v. 4, no. 1, p. 55-79. https://doi.org/10.5424/sjar/2006041-178.

Gaylarde, P.M., and Gaylarde, C.C., 1998, A rapid method for the detection of algae and cyanobacteria on the external surfaces of buildings, in Gaylarde, C.C., Barbosa, T.C.P., and Gabilan, N.H., eds., Proceedings of the Third Latin American Biodegradation and Biodeterioration Symposium: The British Phycological Society, paper 37.

Giordano, M., Mobili, F., Pezzoni, V., Hein, M.K., and Davis, J.S., 2000 , Photosynthesis in the caves of Frasassi (Italy): Phycologia, v. 39, p. 384 389. https://doi.org/10.2216/i0031-8884-39-5-384.1.

Hanlin, R.T., 1994, Microcycle conidiation-a review: Mycoscience, v. 35, p. 113-123. https://doi.org/10.1007/BF02268539.

Hsu, M.J., and Agoramoorthy, G., 2001, Occurrence and diversity of thermophilous soil microfungi in forest and cave ecosystems of Taiwan: Fungal Diversity, v. 7, p. 27-33.

Hofmann, G., Werum, M., and Lange-Bertalot, H., 2013, Diatomeen im Süßwasser - Benthos von Mitteleuropa. Bestimmungsflora Kieselalgen für die ökologische Praxis: Königstein, Koeltz Scientific Books. 908.

Isola, D., Zucconi, L., Onofri, S., Caneva, G., de Hoog, G. S., and Selbmann, L., 2016, Extremotolerant rock inhabiting black fungi from Italian monumental site: Fungal Diversity, v. 76 , no. 1, p. 75-96. https://doi. org/10.1007/s13225-015-0342-9.

John, D.M., Whitton, B.A., and Brook, A.J., eds., 2003, The Freshwater Algal Flora of the British Isles: an Identification Guide to Freshwater and Terrestrial Algae: UK, Cambridge University Press. 702 p.

Klemenčič, A.K., and Vrhovšek, D., 2005, Algal flora of Krška Jama Cave, Slovenia: Acta Musei Nationalis Pragae, Series B, Historia Naturalis, v. 61 , no. $1-2$, p. $77-80$

Knott, N.A., Underwood, A.J., Chapman, M.G. and Glasby, T.M., 2004, Epibiota on vertical and on horizontal surfaces on natural reefs and on artificial structures: Journal of the Marine Biological Association of the United Kingdom, v. 84, p. 1117-1130. https://doi.org/10.1017/ S0025315404010550h.

Komárek, J., 2013, Süßwasserflora von Mitteleuropa, Bd 19/3: Cyanoprokaryota 3: Heterocystous genera: Heidelberg, Springer Spektrum, $1130 \mathrm{p}$.

Komárek, J., and Anagnostidis, K., 1998, Cyanoprokaryota 1. Teil/ $1^{\text {st }}$ Part: Chroococcales, in Ettl, H., Gärtner, G., Heynig, H., and Mollenhauer, D., eds., Süßwasserflora von Mitteleuropa 19/1: Jena-Stuttgart-Lübeck-Ulm, Gustav Fischer, 548 p.

Komárek, J., and Anagnostidis, K., 2005, Cyanoprokaryota 2. Teil: Oscillatoriales, in Ettl, H., Gärtner, G., Heynig, H., and Mollenhauer, D., eds., Süßwasser flora von Mitteleuropa, 19/2: Berlin, Spektrum Akademischer Verlag, 759 p. 
Komárek, J., and Fott, B., 1983, Chlorophyceae (Grünalgen). Ordnung: Chlorococcales. Das Phytoplankton dês Süßwassers, Systematik und Biologie, in Elster, H.J., and Ohle, W., eds., Die Binnengewässer XVI, 7 (1): Stuttgart, Germany, Schweizerbart'sche Verlagsbuchhandlung, 1044 p.

Krieger,W., and Gerloff, J., 1962, Die Gattung Cosmarium: Weinheim, Verlag von J. Cramer. 410 p.

Lamprinou, V., Danielidis, D.B., Economou-Amilli, A., and Pantazidou, A., 2012, Distribution survey of Cyanobacteria in three Greek caves of Peloponnese: International Journal of Speleology, v. 41, no. 2, p. 267-272. https://doi.org/10.5038/1827-806X.41.2.12.

Lamprinou, V., Danielidis, D.B., Pantazidou, A., Oikonomou, A., and Economou-Amilli, A., 2014, The show cave of Diros vs. wild caves of Peloponnese, Greece - distribution patterns of Cyanobacteria: International Journal of Speleology, v. 43, no. 3, p. 335-342. https://doi.org/10. 5038/1827-806X.43.3.10.

Lamprinou, V., Pantazidou, A., Papadogiannaki, G., Radea, C., and Economou-Amilli, A., 2009, Cyanobacteria and associated invertebrates in Leontari Cave, Attica (Greece): Fottea, v. 9, no. 1, p. 155-164. https:// doi.org/10.5507/fot.2009.014

Lapaire, C.L., and Dunkle, L.D., 2003, Microcycle conidiation in Cercospora zeaemaydis: Phytopathology, v. 93, p. 193-199. https://doi.org/10.1094/ PHYTO.2003.93.2.193.

Martínez, A., and Asencio, A.D., 2010, Distribution of cyanobacteria at the Gelada Cave (Spain) by physical parameters: Journal of Cave and Karst Studies, v. 72, no. 1, p. 11-20. https://doi.org/10.4311/jcks20091sc0082.

Mazina, S.E., and Maximov, V.N., 2011, Photosynthetic organism communities of the Akhshtyrskaya Excursion Cave: Moscow University Biological Sciences Bulletin, v. 66, no. 1, p. 37-41. https://doi.org/10. 3103/S009639251101007X

Mulec, J., and Kosi, G., 2008, Algae in the aerophytic habitat of Račiške ponikve cave (Slovenia): Natura Sloveniae, v. 10, no. 1, p. 39-49.

Mulec, J., Kosi, G., and Vrhovšek, D., 2008, Characterization of cave aerophytic algal communities and effects of irradiance levels on production of pigments: Journal of Cave and Karst Studies, v. 70, no. 1, p. $3-12$.

Mulec, J., Krištůfek, V., and Chroňáková, A., 2012, Comparative microbial sampling from eutrophic caves in Slovenia and Slovakia using RIDA ${ }^{\circledR}$ COUNT test kits: International Journal of Speleology, v. 41, no. 1, p. 1-8. https://doi.org/10.5038/1827-806X.41.1.1.

Ogórek, R., Lejman, A., and Matkowski, K., 2013, Fungi isolated from Niedźwiedzia Cave in Kletno (Lower Silesia, Poland): International Journal of Speleology, v. 42, no. 2, p. 161-166. https://doi.org/10.5038/ 1827-806X.42.2.9.

Ogórek, R., Dylag, M., Kozak, B., Višňovská, Z., Tančinová, D., and Lejman, A., 2016, Fungi isolated and quantified from bat guano and air in Harmanecká and Driny Caves (Slovakia): Journal of Cave and Karst Studies, v. 78, no. 1, p. 41-49. https://doi.org/10.4311/2015MB0108.

Pantazidou, A., and Roussomoustakaki, M., 2005, Biodiversity and ecology of cyanobacteria in a variety of hypogean ecosystems (Greece): Proceedings of the 14th International Congress of Speleology, vol. 2: Athens, Hellenic Speleological Society, paper P-29, p. 624-627.

Popović, S., Subakov Simić, G., Stupar, M., Unković, N., Predojević, D., Jovanović, J., and Ljaljević Grbić, M., 2015, Cyanobacteria, algae and microfungi present in biofilm from Božana Cave (Serbia): International Journal of Speleology, v. 44, no. 2, p. 141-149. https://doi.org/10.5038/ 1827-806X.44.2.4.

Poulíčková, A., and Hašler, P., 2007, Aerophytic diatoms from caves in central Moravia (Czech Republic): Preslia, v. 79, p. 185-204.
Pusz, W., Ogórek, R., Uklańska-Pusz, C.M., and Zagożdżon, P., 2014, Speleomycological research in underground Osówka complex in Sowie Mountains (Lower Silesia, Poland): International Journal of Speleology, v. 43, no. 1, p. 27-34. https://doi.org/10.5038/1827-806X.43.1.3.

Raper, K.B., and Fennell, D.I., 1965, The Genus Aspergillus: Baltimore, The Williams and Wilkins Company, $686 \mathrm{p}$.

Rindi, F., 2007, Diversity, distribution and ecology of green algae and cyanobacteria in urban habitats, in Seckbach, J., ed., Algae and Cyanobacteria in Extreme Environments: Dordrecht, Springer, p. 621638. https://doi.org/10.1007/978-1-4020-6112-7_34.

Roldán, M., and Hernández-Mariné, M., 2009, Exploring the secrets of the three-dimensional architecture of phototrophic biofilms in caves: International Journal of Speleology, v. 38, p. 41-53. https://doi.org/10.5038/ 1827-806X.38.1.5.

Ruibal, C., Gueidan, C., Selbmann, L., Gorbushina, A.A., Crous, P.W., Groenewald, J.Z., Muggia, L., Grube, M., Isola, D., Schoch, C.L., Staley, J.T., Lutzoni, F., and De Hoog, G.S., 2009, Phylogeny of rock-inhabiting fungi related to Dothideomycetes: Studies in Mycology, v. 64, p. 123-133. https://doi.org/10.3114/sim.2009.64.06.

Samson, R.A., Houbraken, J., Thrane, U., Frisvad, J.C., and Andersen, B., 2010, Food and Indoor Fungi: The Netherlands, CBS-KNAW Fungal Biodiversity Centre Utrecht, $390 \mathrm{p}$.

Samson, R.A., and Varga, J., 2007, Aspergillus Systematics in the Genomic Era: Utrecht, The Netherlands, Fungal Biodiversity Centre, Studies in Mycology 59, $206 \mathrm{p}$.

Selvi, B., and Altuner, Z., 2007, Algae of Ballica Cave (Tokat-Turkey): International Journal of Natural and Engineering Sciences, v. 1, no. 3, p. 99-103.

Starmach, K., 1972, Chlorophyta III. Zielenice nitkowate: Ulotrichales, Ulvales, Prasiolales, Sphaeropleales, Cladophorales, Trentepohliales, Sipholales, Dichotomosiphonales: Warszawa and Krakow, Panstwowe Wyadwnictwo Naukowe, series Flora slodkowodna Polski 10, 750 p.

Sterling, D.A., and Lewis, R.D., 1998, Pollen and fungal spores indoor and outdoor of mobile homes: Annals of Allergy, Asthma and Immunology, v. 80, p. 279-285. https://doi.org/10.1016/S1081-1206(10)62971-7.

Ter Braak, C.J.F., and Šmilauer, P., 2012, Canoco Reference Manual and User's Guide: Software for Ordination, version 5.0: Ithaca, USA, Microcomputer Power, $496 \mathrm{p}$.

Urzi, C., and de Leo, F., 2001, Sampling with adhesive tape strips: an easy and rapid method to monitor microbial colonization on monument surfaces: Journal of Microbiological Methods, v. 44, p. 1-11. https://doi.org/10. 1016/S0167-7012(00)00227-X.

Urzì, C., de Leo, F., Bruno, L., and Albertano, P., 2010, Microbial diversity in paleolithic Caves: a study Case on the Phototrophic Biofilms of the Cave of Bats (Zuheros, Spain): Microbial Ecology, v. 60, p. 116-129. https:// doi.org/10.1007/s00248-010-9710-x.

Vanderwolf, K.J., Malloch, D., McAlpine, D.F., and Forbes, G.J., 2013, A world review of fungi, yeasts, and slime molds in caves: International Journal of Speleology, v. 42, no. 1, p. 77-96. https://doi.org/10.5038/ 1827-806X.42.1.9.

Watanabe, T., 2010, Pictorial Atlas of Soil and Seed Fungi: Morphologies of Cultured Fungi and Key to Species, third edition: Boca Raton, Florida, US, CRC press, $426 \mathrm{p}$.

Whitton, B.A., ed., 2012, Ecology of Cyanobacteria II, Their Diversity in Space and Time: London, UK, Springer, $760 \mathrm{p}$.

Woudenberg, J.H.C., Groenewald, J.Z., Binder, M., and Crous, P.W., 2013, Alternaria redefined: Studies in Mycology, v. 75, p. 171-212. https://doi. org $/ 10.3114 / \operatorname{sim} 0015$. 